\title{
Studies on evaluation of fungicides against Curvularia lunata in maize
}

\author{
Kotramma C. Adaangadi*, S. I. Harlapur ${ }^{1}$, Savita Chakrasali ${ }^{1}$ and Basamma R. Hadimani ${ }^{1}$ \\ Regional Research Station (S.D.A.U.), BHACHAU (GUJARAT) INDIA \\ (Email : kotramma.addangadi@gmail.com)
}

\begin{abstract}
Maize is an important cereal crop of India. Maize not only an important human nutrient but also a basic element of animal feed and raw material for manufacture of many industrial products. Recently the crop is severely affecting with Curvularia leaf spot of maize caused by Curvularia lunata (Wakker) Boedijn and it is endemic in the maize growing areas of northern Karnataka. Fungicides were evaluated by poison food technique. Among the five contact fungicides tested at three concentrations, mancozeb 75\% WP showed cent per cent inhibition. Among all the systemic fungicides tested triazoles were found to be a most effective in inhibiting the mycelial growth of the fungus at all the concentrations. The combiproduct fungicides viz., carboxin $37.5 \%$ + thiram 37.5\% WS, captan 70\% + hexaconazole 5\% WP, iprovalicarb 5.5\% + propineb $61.25 \% \mathrm{WP}$ and pyraclostrobin $13.3 \%$ + epoxiconazole 5\% WP gave 100 per cent inhibition at all the concentrations tested.
\end{abstract}

Key Words : In vitro, Fungicides, Curvularia lunata, Maize, Evaluation

View Point Article : Adaangadi, Kotramma C., Harlapur, S.I., Chakrasali, Savita and Hadimani, Basamma R. (2018). Studies on evaluation of fungicides against Curvularia lunata in maize. Internat. J. agric. Sci., 14 (1) : 225-228, DOI:10.15740/HAS/IJAS/14.1/ 225-228.

Article History : Received : 07.03.2017; Revised : 07.12.2017; Accepted : 19.12.2017

\footnotetext{
* Author for correspondence:

${ }^{1}$ Department of Plant Pathology, College of Agriculture, University of Agricultural Sciences, DHARWAD (KARNATAKA) INDIA
} 